\title{
Kashmir Conflict and the Advent of Torture: An Overview
}

\section{Inamul Haq}

\author{
Centre for Gandhian Thought \\ and Peace Studies, School of \\ Social Science. Central \\ Univesity of Gujarat, \\ Gandhinagar
}

mantooinam72@gmail.com

\begin{abstract}
Modern states have built burgeoning detention facilities like immigration centers, prisons and police cells that engage in torture and other cruel, inhuman treatments. The law enforcement agencies engage in torture and other cruel, inhuman and degrading treatment or punishment in the name of counterterrorism, security threats and soon. The state uses torture and makes it clear that enhanced interrogation techniques makes a person from kidnapping to extra-ordinary rendition, from citizen to unlawful enemy combatant and from human to terrorist. The valley of Kashmir faces torture and other cruel inhuman treatments since insurgency began in 1990's, with violent uprising and have elicited terrorism. Methods like torture is used as a tool of counter-insurgency by Indian security forces. The government of India used all efforts to crush the movement of selfdetermination of Kashmir. The strong response from India violates the human rights and international humanitarian laws. The law enforcement agencies, army and para- military forces have engaged in reprisal attacks against civilians resulting in indiscriminate firing, search operations, gang-rapes and burning of houses in the valley. After 1990, the situation in the Kashmir valley deteriorated and Kashmir was declared a disturbed area and laws like Disturbed Area Act (DAA) 1990, Armed Forces Special Powers Act (AFSPA) 1990 and Public Safety Act (PSA) 1978 were imposed. The purpose of the paper is to examine the concept of Torture in Kashmir valley and bring to light the plight of the victims in the valley.

KEYWORDS

Kashmir Conflict; Insurgency; Torture; AFSPA and Social

Consequences
\end{abstract}

\section{INTRODUCTION}

The valley of Kashmir has stood for peaceful observation, intellectual advancements and religious diversity from the ancient times. This diversity, evident from the blend of Islam, Hinduism, Sikhism and Buddhism in the state made advancement of warfare rather than cultural advancement. The insurgency in late 1980's and counter- insurgency from the Indian side in the valley not only threatened Kashmir apart, but also laid its shakes on the rest of the world. The valley of Kashmir is considered as the hazardous place on earth. Since the partition of India and Pakistan in 1947, the state of Jammu and Kashmir becomes an unresolved land. The people who live there has been at the roots of constant tension between the world's largest democracy (India) and its neighbor (Pakistan). To highlight their advanced technology, the two countries fought each other in battle ground as well as on negotiating table. The uncertainty and lack of any conclusive resolution to the political dispute have left the population of the state of Jammu and Kashmir divided and uncertain about their future. The land of Kashmir, with immense beauty and tourist industry disappear completely in the face of military invasions and terrorist activities (Schofield, 2010). 
After seven decades and twenty seven years of heightened the conflict of Kashmir in the sub-continent. The people of Kashmir valley have been systematically alienated in their home land by dominant political and military culture. The people of Kashmir valley are not only deprived of their sovereignty in the democratic India, but were treated like nationless outsiders in other parts of India. The state of Jammu and Kashmir is a disputed territory of India and Pakistan. However, the Indian occupied Kashmir is full of paramilitary troops, detention centers, barbed wires, torture, disappearances, and custodial killings that catches the glimpses of their sons, fathers, brothers and husbands, who were either detained, killed, tortured or disappeared (Khan, 2016).

\section{RESEARCH METHODOLOGY}

This study is based on descriptive analysis that can be studied by applying the exploratory method. This study would involve qualitative research that is empirically grounded. The research would examine the concept of torture in Kashmir valley through the analyses of data available. The research work is based both on primary as well as secondary sources. Primary data consists of official documents published by government of India and reports of various organizations like Amnesty International, Human Rights watch, Asian Centre of Human Rights. The secondary sources are books and articles that are published in national and international journals, newspapers report and on the internet website.

\section{RESULT}

\section{The Kashmir Conflict}

The state of Jammu and Kashmir lies in the heart of Asia. It is situated between 32.17 and 36.58 degree north latitude and 37.26 and 80.30 degree east longitude. In the west, the state is bounded by Pakistan, in north east by China, by Afghanistan in the North West and in south by India (Tabasum 2012:5). The area of the state is 85,806 square miles and total population stands for 1.25 crore [1, 25, 41302] (Census, 2011).

The conflict of Kashmir is deeply rooted in the colonial history of the sub-continent (Ganguly, 1990:57).The dispute of Kashmir between India and Pakistan is as old as the two countries themselves, dating back to the Partion and independence from Britain in 1947 (Bose, 2003). At present the parts of Kashmir are not only occupied by India and Pakistan, but china also occupied some parts of it (Choudary, 2010). The state of Jammu and Kashmir has Muslim majority population and was variously ruled by central and west originating Mughal-afghan dynasties. In the nineteenth century, the Britishers take it from Sikhs and sold to a Hindu Dogra Maharaja Gulab Singh in the treaty of Amritsar for seventy five lakh rupees (Kaul, 2010:43). Thus, the valley of Kashmir witnessed the Dogra rule from 18461947. The people led a miserable life and were treated as slaves. The imposition of heavy taxes, capital punishment and the constant terror was created by the Dogra's against Kashmiri Muslims (Ahmad, 2010).

The origins of conflict of Kashmir lies in the sub-continent's Partion in 1947 created the independent states of India and Pakistan. With this the hundreds of nominally independent princely states were absorbed into India and Pakistan. The Dogra ruler Maharaja Hari Singh of Kashmir wants to remain independent and refused to accede to either nation (Dewan, 2011). In 1947, the maharaja faced the armed revolt by Muslims from Poonch. The revolt then spread in other parts of Jammu and Kashmir. In order to stabilize the situation, the maharaja signed a still stand agreement with Pakistan. In August/September 1947, the situation deteriorated and Kashmiri Muslims revolted openly. The tribesmen from Pakistan's North West frontier province also joined in the armed insurrection. By the October 1947, the tribesmen capture the several towns and massacred a large number of civilians and advanced 
to capture the capital of valley (Husain, 2009: 1008). To crush the rebels from the state the maharaja to seek assistance of India's Prime Minister Jawahar Lal Nehru, who agreed to send troops only if Kashmir formally acceded to India. On October 27, 1947 the Maharaja agreed to sign the instrument of accession to India on the condition that Kashmir should be permitted to retain its own constitution (Dewan, 2011).

In the same year, both India and Pakistan fought their first war on Kashmir dispute and India took the matter before United Nations (UN). With the intervention of UN, both countries signed the cease-fire line on January 1, 1949 (Hussain, 2009:1008). In 1965, once again both the countries fought another war over Kashmir and divided the old line of control (LOC) of the state into four political units.

- The three regions Jammu, Kashmir and ladakh which is known as Indian occupied Kashmir.

- Azad Kashmir came to known as Pakistan occupied Kashmir.

- The northern area which is administered by Pakistan.

- Aksai-Chin which was taken and controlled by China (Ibid, 2009: 1009).

In January 1966, Tashkent Agreement was signed between India and its neighboring country Pakistan and both countries decided to solve the Kashmir dispute through peaceful negotiations (Gopalan 2007). However in 1971 both countries once again meet each other in the war, when India supported East Pakistan now (Bangladesh) for its independence. In 1972, an agreement was signed and both countries decided to end their conflicts through bilaterally and this agreement came to be known as Shimla Agreement (Singh, 2011: 12). The main features of Shimla agreement is that both the countries should respect each other's territorial integrity, sovereignty, political independence and non- interference in each other's internal affairs. Besides that, both countries lay emphasis on cooperative relationship with special focus on people to peoples contact and uphold the inviolability of the line of control (LOC) in Jammu and Kashmir

\section{Insurgency and Counter-Insurgency}

After Shimla Agreement, Sheikh Abdullah and Kashmir moves closer to India and signed an accord with Indira Gandhi in 1975, which came to be known as Kashmir Accord. This accord strengthened the Control over legislation in Kashmir. Later on both congress and National Conference made an alliance and congress made its presence in the elections of valley. However in 1977 the state congress withdrew its support of the Abdullah Government and thus the alliance between National Conference came to an end and sheikh started speaking about the plebiscite and Independence. This is the starting point that mobilized the people of valley against India and strengthened the wave of the secessionist's sentiments were alive among Kashmiri's from 1947, which later on comes out in the form of insurgency (Pandita, 2003). Ashutosh Varsney (1992), argues that there are main three reasons that give rise to the insurgency. In the Kashmir valley there was a clash of three competing visions of nationalism: Kashmiri, secular and Islamic. On the other hand Prem Shankar Jha (1991), an Indian journalist argues that the basic reason for the outbreak of insurgency in the valley can be traced to the middle- class frustration. In the Kashmir valley, the educated youth faced the problem of unemployment opportunities. While as the main reason for the outbreak of insurgency is a result of political mobilization which increased dramatically after 1970's. The growth of educational institutions and madrassas boost it after 1983. The increase in education made an awareness among the people about the politics at local, national and international levels. The political mobilization in the valley was also supported by the expansion of mass-media (Ganguly, 1996). 
In 1980, the Islamization of Kashmir spread quickly and the names of two thousand five hundred villages were changed to the Islamic names. The Kashmiri leader sheikh Abdullah, once again returned to the same position of 1930's by giving the communal speeches in Mosques and the slogans like Islam is in danger mobilized the youth. The Islamic literature was being distributed to create awareness among the people and small pamphlets like Tragedy of Kashmir written by Yousuf Saraf and Kashmiris fight for freedom appeared in the valley created frustration among educated people and created hatredness among them towards India (Pandita, 2003). The influence of Saudi emerged in 1979, by holding an Islamic conference in Srinagar and setup the Jhelum Valley Medical College in 1980, through which the message of radical Islam and Communalism was been spread in the valley. The establishment of Madrasahs from the early 1980's also planted the seeds of Islamic fundamentalism in Kashmir. These madrasahs and schools were funded by the Arab countries and propagated the fundamentalist approaches and completely rooted the Sufi culture for which Kashmir was known throughout the world. Besides that the AfghanSoviet war also influenced the people of Kashmir and their emotions raised to the high level. The war not only lifted their spirit but also served a very important practical purpose. The young generation considered to fight against India is their religious war (Pandita, 2003). The spread of modernization and communication created a political conscious among Kashmiri educated and ambitious youth and they got dissatisfied with the political system of the valley. The rise of unemployment in the valley also gave a wide spread frustration among youth against their leaders and policies of central government (Ganguly, 2007). These all events come out together in the form of insurgency after the rigid elections of 1987, in which a new party namely Muslim United Front (MUF) comes to the forefront (Khan, 2009). The MUF, which had the support of pro- independence activists, Islamic fundamentalists and many frustrated Kashmiri youth, contested the election for state Assembly (Mukherjee, 2014).

In this election, at least seventy five percent polling was recorded in the state which is considered as highest ever in the valley. The alliance of National Conference and Congress claimed sixty- six seats. MUF had contested on forty- four seats and won only four. Balraj Puri (1993) stated that the result of elections gives strength to the fundamentalist forces in the valley. Khemlata wakhloo, a Kashmiri pundit women who was at that time a prominent member of National Conference (NC) states that there was a popular support in favor of MUF.The leaders of the MUF were trying to change the political system by democratic and peaceful methods and by the process of elections. They were arrested and tortured by the security forces and police and created the lawlessness and a spiral of violence in the region, causing many young educated and unemployed youth to join the militant ranks (Akhtar, 1991). Most of the educated youths joined the liberation front which was active from 1964 and came to known as (JKLF) Jammu and Kashmir Liberation Front (Puri, 1993). In 1988, the wide protest began in the valley along with anti- India demonstration resulted into strikes, arrests and torture by the police (Schofield, 2010). The turning point was the kidnapping of Rubbia Sayeed, daughter of Mufti Mohammad Sayeed on December 8, 1989 in exchange for the release of five JKLF leaders (Puri, 1993). The insurgency spread rapidly in all over the valley after the massacre of Gawkadal happened in which fifty-three civilian died and hundreds were wounded by the indiscriminate firing of security forces on January 20, 1990 (Wani, 2014). Soon after the massacre all Kashmiri people men, women and children led demonstration peacefully and non-violently but they were met with disproportionate and indiscriminate lessons from security forces and the roots of self- determination and freedom gets stronger.

In response the Indian Government launched a massive crackdown on the militants. With the resignation of Farooq Abdullah, the governor rule was imposed in the valley on January 
19, 1990 and former governor K. V Krishna Rao was replaced and Jaghmohan Molhotra was appointed as new governor (Schofield, 2010). The new governor takes all repressive measures like torture, rape, arresting, and indiscriminate firing to deal with the insurgent movement which was growing stronger with the assistance of Pakistan, Afghanistan and Arab countries. India's response to the counter- insurgency can be examined in the light of two proclaimed models. The Criminal Justice Model (CJM) and War Model (WM). The CJM focuses and protects the democratic principles as being the fundamental premise in the fight against terror. While as, WM places a strong emphasis on counter- terrorism rather than upholding democratic rights (Kapoor, 2007). India applies the WM while dealing with the insurgents of Kashmir and deployed military and para- military forces, who leads the operation with the view to countering the insurgents who were supported by Pakistan and other Muslim countries. For India, insurgency was a proxy war and for its elimination or suppression, India take all possible measures, and these were so effective that it leads to human rights violation in the valley and it also gives birth to the various terrorist organizations in the valley.

\section{Torture}

The term torture is a generic concept and can be defined, debated and deliberated under various conditions, in diverse contexts and claims. There is no consensus among the scholars, practitioners about the meaning of the term. It has been used as an investigative technique inflicted on a third person for the purpose of extracting information or confession. According to the United Nations Convention on 10 December 1984, Torture means any kind of act which causes severe pain or sufferings whether physical or mental and is intentionally inflicted on a person for such purposes to obtain information or a confession. This definition does not include "pain or suffering arising only from inherent in or incidental to lawful sanctions" (White, 2009 \& Garcia, 2009).

Torture was legally and morally accepted in ancient, medieval and early modern societies. Torture was banned in the west during eighteenth and nineteenth centuries (Einolf, 2007). During the twentieth century, torture increased greatly in Europe with the rise of communists and fascist states and the coming of Two World wars. Torture decreased again after the defeat of axis powers in 1945 and the fall of communism in 1989 (ibid, 2007).

At global level the idea of democracy is strong. In democracy it is necessary for every society to become liberal. The third world countries have also adopted democracy. The problems like ethnic diversities, minorities, insurgencies and succession movements, have also engaged them in many violent activities against their citizens including torture, killing and displacement (Wisnewski, 2010). Torture becomes an effective tool among these countries. The use of such violence against the people becomes problematic. Richards and Cengranelli (1999) call them "illiberal democracies" where elections occur and the other features of democracy such as minority rights, the rule of law and independent judiciary are not present. Torture is a crime as it corrupts moral understanding of those countries that are practicing it and tends to radicalize the hearts and minds of communities to which the victim belongs. (Miller, 2010). Alex Bellamy (2006) argues that torture and terrorism go hand in hand and are primarily linked because both violate the non-combatants. It creates an environment in which the warrant and justification of one type of violence easily justify the other type (Stritzke et: al 2009:5).

Torture is of so many types like judicial, punitive, interrogational, dehumanizing, and terroristic. The interrogation practices employed upon by torturers are waterboarding, beating, electrocuting, burning, and forcing sexual acts etc. United Nations Convention (1984) identifies four reasons of torture. 
- To obtain information

- To obtain a confession

- To punish

- To force the sufferer or others to act in definite ways (Miller, 2009).

Torture is considered a crime against humanity and is prohibited in an extensive range of human rights conventions. Article 5 of the Universal Declaration of Human Rights (1948) states no one should be subjected to torture or to cruel, inhuman or degrading treatment or punishment. Geneva Convention (1949) prohibits violence to life and person in particular, cruel treatment and torture and outrages upon personal dignity. Torture is also prohibited by European Convention on Human Rights (1950), the African Charter on Human and People's Rights (1969), the Inter-American Convention to Prevent and Punish Torture (1985), International Convention on Civil and Political Rights (1976), and Genocide Convention (1948) (Miller, 2009 \& Bellamy, 2009:30).

The torture in Kashmir was present from the early period and continued till Dogra rule. Later on after accession torture was happening among local parties like Muslim United Front (MUF) and the members of National Conference (NC) after their division in 1937. However torture became a permanent tool and a method of counter-insurgency. The movement of selfdetermination which turned violent in 1990 was supported by all Kashmiris whether government employee, policeman or teacher. The situation worsened and Indian forces resorted to torture and other cruel inhuman and degrading treatments. The security forces use the brutal and cruel measure which includes identification parades, house to house searches, custodial killings, illegal detention, rape and molestation of Kashmiri women and other coercive methods (Hajni, 2008).

In August 1992, various operations to combat terrorists was carried out by Indian security forces like 'Operation Tiger'. This operation was considered as brutal measure taken by Indian government, in which the execution of the detainees increased to a greater extent. The other operations were carried out in the valley having code names like Shiva, Eagle and Cobra. The main goal of these operations was to create an intense fear among the people of valley, who were demanding separation from the India (Human rights watch, 1993: 22). Torture became of a tool to get information about the militants or forced to confess militant activity (Physicians for Human Right, 1993). The security forces carried out a ruthless campaign of terror against the people who are fighting for their freedom (Selfdetermination). Unrestricted arbitrary powers were given to the security forces to suppress the movement in the valley. As a result thousands of Kashmiri were killed, injured, prosecuted or arrested. India government describes the insurgency as law and order problem and in order to deal with the situation, several oppressive laws have been put into force, which becomes a great reason for the human right violation in the valley. The security forces used different forms of torture in the valley. Besides that crackdown, arson, burning of shops and houses became a custom of Indian security forces. Custodial killing, arrest without warrant were the tools adopted by the forces (Schofield, 2010).

\section{Armed Forces Special Power Act (1990)}

Since the beginning of the armed struggle between armed groups and security forces of India, increased the violence in the Kashmir valley. The valley of Kashmir became one of the most heavily militarized place where special laws like Disturbed Area Act (DAA), Armed Forces Special Powers Act (AFSPA) and Public Safety Act (PSA) are currently promulgated (Singh, 2011). These laws gives open hands to the security forces. These laws violates the fundamental rights that are enshrined in Article 21 and 22 of the Indian constitution like right to life, liberty, speech, expression, free movement, peaceful assembly and freedom of 
religion. With the imposition of law, the human rights violation began to take place like rape, death, custodial torture, looting of property, disappearance and extra-judicial killings (Das, 2011). The main provisions of AFSPA act which allows security forces to impose torture and other cruel treatments. Under the Act, there is no clear definition of what constitutes a "dangerous or disturbed condition." As per Section 2 (b) of the Act, "disturbed area" means "an area which is for the time being declared by notification under section 3 to be a disturbed area.

The section 04 of the Act states that any commissioned officer, warrant officer, noncommissioned officer or any officer equivalent rank can

(a) Use force or indiscriminate firing in order to maintain public order. He can kill any person who is acting in contravention of any law and prohibit the assembly of five members together or the carrying of weapons or of things capable of being used as weapons or firearms, ammunition or explosive substances

(b) He can destroy any arms hideout or houses of common people from where armed attacks are made, likely to be made or attempted to made.

(c) Can arrest anyone without warrant, any person who has committed a cognisable offence or against whom a reasonable suspicion exist that he has committed or is about to commit a cognisable offence and may use such force as may be necessary to effect the arrest;

(d) Can enter and search houses without any restriction, they can use force if feels it necessary.

The section 04 of the AFSPA allows security forces and police officers to impose torture and other coercive methods to anyone without any evidence. This section also allows security forces to destroy property and detain any individual on the basis of suspicion and allows indiscriminate firing for the maintenance of law and order. In the summer of 2016, more than ninety youth of Kashmir were killed in cold blood by the security forces without any evidence. The killing of Burhan Muzafar Wani on July 08, 2016 by security forces created chaos among Kashmiri people and people openly defied curfews, crackdowns and lathi charges in solidarity with the rebel. However, the presence of laws gave free hands to Indian army and they used force and made mass killings.

Article 5 of this Act is that any person arrested and taken into custody can be handover to the officer in charge of any nearest police station without any delay (Noorani, 2009). This means that any one arrested or detained by security forces should be handed to police first for the investigation. It does not happen in Kashmir valley in reality. Any one arrested on by security forces were tortured and if died in custody then becomes disappeared forever. The evidence is that still in Kashmir more than one thousand people are disappeared and there is no evidence about them whether they are dead or alive.

\section{Consequences of Torture in Kashmir Valley}

The conflict of Jammu and Kashmir in 1989 with a political demand of self- determination has been met with a brutal response of state and has claimed gross human rights violation. The oppressive response used by Indian state to suppress the movement is torture, rape, enforced disappearance, custodial deaths and burning of houses in the valley, violence laid its impacts deeply in the social life (Shafi and Hassan, 2013). After insurgency all these violence's had a serious effect on mental and physical health in all Kashmiri in all groups, classes and communities in all areas from last twenty five years.

The depression is considered as most important feature of mental health. It has been analyzed that people in the valley face depression at individual and collective level. Due to depression most of the people take drugs. A survey conducted by Action Aid international 
in Kashmir in 2000- 2001. According to them 59.30\% males and 39.50\% females were suffering from depression and hypertension. After 1990, anxiety emerged as socialpsychological problem in Kashmir after counter- insurgency measures adopted by the security forces. This created the feeling of insecurity among individuals. In the valley usually no one is sure to return home safely in the evening. The environment of torture, killing and disappearances of Kashmiri youths led to psychological problems related to anxiety. There were hundreds and thousands of such cases in the past twenty five years mainly because of the impact of militancy and militarization (Dabla, 2012).

The valley of Kashmir has been in conflict between government forces and militants from the last two decades. Bomb attacks and shoot-outs from both sides have affected the ordinary life of common people. Human rights abuses from governmental forces and militants are reported in the form of arrest, extra-judicial killing, house to house searches, abductions and torture. The presence of military personnel's in the valley created a fear, threat and insecurity among people. The disappearance of thousands of Kashmiri youth has made a measurable economic and mental impact. The earning members of the family who missed from insurgency leaving behind half-widows. There is no accurate number of half- widows as per Pervez Imroz, a Human rights Activist and Lawyer of Srinagar High Court argues that their number ranges from 1000- 1500. The members picked on suspicion by security forces leading to mental torture for the whole family. The half-widows do not know about their husbands whether they are dead or alive and lived on the hope that one day they may return home. Many women whose husbands have disappeared prefer to wait for them and do not remarry for the fear of social isolation (Shafi and Hassan, 2013). The suicides are common after insurgency, because of impotency among youth due to the infliction of torture. With this most youths faces the problems of psycho-sexual malfunction. They were interrogated by security forces with electric currents passed through their genitals, suppressed with heavy rollers, removing of finger nails, waterboarding, pouring petrol into anus like techniques were inflicted on youths of both Muslims and Pundits of Kashmir.

The rise of militancy after 1990 created so much human rights violations against Kashmiri pundits in the valley. They were suffered with loot, torture, rape, threating letters, telephone calls, notices on their doors and warnings through newspapers. The Kashmiri pundits were forced to exile from the valley and they had to leave all their customs, traditions and celebrations (Cohen, 1998: 210). The Kashmiri pundits faced mental torture from the last twenty- five years. The owners became the migrants soon after the insurgency. The pundits of the valley still remembers the beautiful memories of the valley, brotherhood and tolerance with Muslim neighbors. However, they became the targets of militant groups soon after insurgency. While as the Muslims became the victims of Indian security forces. By comparing both, the pundits of the valley only face mental torture. According to Rahul Bhat, a Kashmiri- pundit Bollywood actor that Kashmiri pundits are well settled in India and are living a good life. While as Muslims in Kashmir have suffered more than pundits (Ali, 2011). The Muslims of valley faced torture both physically as well as mentally from the hands of police, security force and militant groups from last two decades.

\section{Limitation of the Study}

The study deals with Kashmir conflict, Insurgency and torture which are very interesting in terms of understanding the basic problem of Kashmir. However, there is no scholarly work on the torture, which is a challenge to discuss in contemporary India. The research needs primary collection of data, which was not possible to collect as the situation of Kashmir remains pandemic mostly. After the abrogation of Article 370, the collection of data becomes even more difficult, due to security lockdown and curfews. 


\section{CONCLUSION}

The conflict of Kashmir is present from the Partition in 1947 and is considered as most hazardous conflict in the South Asia. Both countries (India and Pakistan) fought three wars on Kashmir issue and later on both countries took the matter to the United Nations. After 1972 both countries made an agreement that the dispute of Kashmir should be solved peacefully with bilateral negotiations. However the dispute remains same as it was from 1947 and today the conflict seems to have less to do with Indo- Pak relations.

The valley of Kashmir is one the most militarized conflict zone in the world. The outbreak of insurgency after the 1987 election created panic not only in South Asia but all over the globe. India use counter- insurgency measurements to suppress the voice of selfdetermination and send seven lakh troops to valley. The presence of paramilitary forces in the valley created a terror in the hearts and minds of the people, because these troops used violence instead of love in the valley. In 1990 valley of Kashmir was put under Disturbed Area Act and laws like AFSPA and PSA were imposed. The AFSPA gives security forces extra-ordinary powers in the region and methods like torture, extra-judicial killing, custodial deaths and disappearances existed in the valley. The people of Kashmir became scapegoat of both India and Pakistan, who send armed men in valley to support the freedom movement in Kashmir. Torture, a tool of impunity was commonly used after 1990 in the valley. It is used in both forms physically as well as mentally to the people of valley. The infliction of torture is common practice in the valley and it increased from the 2008 mass- agitation in the valley. After the insurgency, the people of Kashmir face lot of problems in all ways. They face psychological torture more than physical and women are the most victim of this torture. The disappearance of their sons, brothers, fathers or husbands shattered their dreams and psychologically distracted. They are the patients of trauma and blood pressure and also face the problems in every section of their life whether physically or economically. The youth also became the victim of torture. Their potential was destroyed and distracted from the real image of life and gun was given in their hands.

\section{REFERENCES}

Ahmad, Bilal. (2010). "The day we cannot forget" Srinagar: Greater Kashmir, Accessed on 27/12/2014 at Central University of Gujarat (11.16 am).

http://www.greaterkashmir.com/news/2010/Jul/13/the-day-we-can-t-forget-34.asp

All Parties Hurriyat Conference by South Asian Terrorism Portal-A Report

http://www.satp.org/satporgtp/countries/india/states/jandk/terrorist_outfits/Hurriyat

Amnesty International (2011). 'A Lawless Law: Detention under Public Safety Act' London: United Kingdom.

Ali, Tariq (et al). (2011). Kashmir: the case for freedom, UK: Verso.

Bellamy, Alex, J. (2006). "No pain No Gain" Torture and Ethics in war on Terror" International Affairs, 82 (1), 121-148.

Bali, Ajeet, Kumar. (2014). 'Pakistan's policy towards azad Jammu and Kashmir: An overview' The International Journal of Humanities and Social Science.

Bose, Sumatra. (2003). "Roots of conflict, Path to peace" Cambridge: Harvard University Press.

Choudary, Salahuddin Shoaib. (2010). Pakistani rogue policy on Kashmir.Srilanka: Guardian.

Cohen, Stephen, Philip. (1998). 'the Pakistan army: with a new foreword and epilogue' Karachi: Oxford University Press.

Dabla, Bashir, Ahmad. (2012). "Social impact of Militancy in Kashmir" India: Gyan Publishing House. 
Das, Asit. (2011). Armed forces special powers act (AFSPA) and Irom Sharmila's struggle for justice. http://www.countercurrents.org/das191111.htm.

Dewan, Parvez. (2011). the other Kashmir almost everything about. New Delhi: Manas Publications.

Dutt, Sagarika. (2014). South Asia. In Sperling, James. (Ed.), Handbook of governance and security, UK: Edward Elgar Publishing Limited.

Einolf, Christopher. (2007). "The Rise and Fall of Torture: A comparative and Historical Analysis" Sociological Theory, 25(2), 101-121.

Ganguly, Rajat. (2001). India, Pakistan and the Kashmir insurgency: causes, dynamics and prospects for resolution. Asian Studies Review.

Garcia, Michael, John. (2009). Renditions: constraints imposed by law on torture. Congressional Research Service.

Ganguly, Sumit. (1990). “Avoiding war in Kashmir” Foreign Affairs, Vol. 65(5), 57- 73.

Ganguly, Sumit. (1996). 'Conflict and Crisis in South and South West Asia', in (Ed.) Brown, Michael, E, The International Dimensions of Internal Conflict, Cambridge: Harvard university.

Ganguly, Sumit. (1996). explaining the Kashmir insurgency: political mobilization and Institutional decay, International Security, Vol. 21(2): 76-107.

Gopalan, Sandeep. (2007). 'India-Pakistan relations: Legalization and agreement design' Vanderbilt Journal of Transnational Law, Vol. 40 (687).

Hajni, Mehraj. (2008). The Kashmir conflict: a Kashmiri perspective. In swords and ploughshares: the future of Kashmir. University of Illinois at Urbana-Champaign: Program in Arms Control, Disarmament and International Security, Vol. 16.

Human Rights Violations in Jammu \& Kashmir - A Report, Published in Outlook Magazine. http://www.outlookindia.com/article/Human-Rights-Violations-in-Jammu--Kashmir-A-Report/211099.

Hussain, Syed, Rifaat. (2009). "Resolving the Kashmir dispute: blending realism with justice The Pakistan Development Review, Vol. 48 (4), 1007- 1035.

Imroz, Pervez et al (2012). "Alleged perpetrators: stories of impunity in Jammu and Kashmir International Tribunal on Human Rights and Justice in Indian- Administrated Kashmir.

India's Secret Army in Kashmir New Patterns of Abuse Emerge in the Conflict (1996) Human Rights Watch, Vol. 8 (4c), 1- 54.

Jahangir, Mohamad, Saleem and Shafi, Aneesa. (2013). "Status of human rights in democratic setup: Experiences from Kashmir" Journal of Law and Conflict Resolution, Vol. 4(3), 41- 47.

Jha, Prem, Shankar. (1991). frustrated middle-class: roots of Kashmir's alienation. In Ali, Asghar, Engineer. (Ed.), secular crown on fire: the Kashmir problem, Delhi: Ajanta Publications.

Kaldor, Mary. (2012). new and old wars: organized violence in a global era' Cambridge: Polity Press.

Kapoor, VK. (2007). Counter-terrorism responses: A military perspective, Center for Land Warfare Studies: 27-35.

Kaul, Natasha. (2010). "On loving and losing Kashmir" India International center Quarterly, Vol. 37(3/4), 42- 53.

Khan, Nyla, Ali. (2009). Islam, women and violence in Kashmir. New Delhi: Tulika Books. Koul, Mohan, Lal. (1999). 'Kashmir wail of a valley atrocity and terror, Delhi: Gyan Sagar Publications.

Mohiuddin, Lubna (1997). "Human rights violation: A case study of Kashmir" Pakistan Horizon, Vol. 50 (2), 75- 97. 
Miller, Seumas. (2009). "Terrorism and Counter Terrorism" Blackwell Publishing House.

Mukherjee, Kunal. (2013). 'The Kashmir conflict in South Asia: voices from Srinagar' Defense \& Security Analysis, Vol. 30 (1), 44-54.

Noorani, A G. (2009). 'Armed forces (special powers) act: urgency of review' Economic and Political Weekly, Vol. 44 (34), 8-11.

Noorani, A.G. (2002). "Human rights in Kashmir" Economic and Political Weekly, Vol. 37 (12), 1081- 1082.

Pandita, K, N. (2003). “Kashmir question” Kashmir Herald, Vol. 2 (9).

Paul, Staniland. (2012). between a rock and a hard place: insurgent fratricide, ethnic defection and the rise of pro-state paramilitaries, Journal of Conflict Resolution, Vol. 56 (16): 16-40.

Qayoom, Farah. (2014). "Women and armed conflict: Widows in Kashmir" International Journal of Sociology and Anthropology, Vol. 6 (5), 161- 168.

Rape in Kashmir a crime of war, Asia watch and Physicians for Human Rights, Vol. 05 (9).

Shafi, Aneesa and Hassan, Asima. (2013). "Impact of Conflict Situation on Mental Health in Srinagar, Kashmir" Bangladesh e-Journal of Sociology, Vol.10 (1), 101-126,

Stritzke, Werner (et al). (2009). "Terrorism and Torture" New York: Cambridge university press.

Sharma, Surinder, Kumar and Behara, Anshuman. (2014). 'Militant groups in South Asia' New Delhi: Institute for Defense Studies and Analyses.

Shimla agreement, July 02, 1972, Ministry of External Affairs: Government of India. http://www.mea.gov.in/in-focus article.htm?19005/Simla+Agreement+July+2+1972.

Singh, M, Amarjeet. (2011). "Conflict in Jammu and Kashmir", Bangalore: National Institute of Advanced Studies.

South Asian Terrorism Portal (2015). A Report. http://www.satp.org/satporgtp/countries/ india/states/jandk/data_sheets/annual_casualties.htm

Tabasum, Muhammad Tahir. (2012). "Political situation in Kashmir and role of united nations" studies of changing societies: comparative and interdisciplinary focus, Vol. 1 (2), 3- 28.

Ashley, J. (2012). 'The menace that is Lashkar-e- Toiba' Carnegie Endowment for International Peace. http://carnegieendowment.org/files/LeT_menace.pdf.

The Adivasis of Chhattisgarh victims of the Naxalites movement and Salwa Judum campaign. (2006) New Delhi: Asian Center for Human Rights.

The crackdown in Kashmir: Torture of detainees and assaults on the medical community (1993). Physician for Human Right and Asia Watch.

The Human Rights Crisis in Kashmir. (1993) Human Rights Watch.

Torture Trial: A documentary prepared by Pravez Imroz. https://www.youtube.com/watch?v=-FdpaLuqOig.

Tremblay, Reeta, Chowdary. (1996-1997). "Nation, identity and the intervening role of the state: A study of the secessionist movement in Kashmir" Pacific Affairs, Vol. 69 (4), 471- 497.

Varsney, Ashutosh. (1992). three comprised nationalisms: why Kashmir has been a problem. In Thomas, Raju. (Ed.), perspective on Kashmir: the roots of conflict in South Asia. Boulder, co: Westview Press.

White, E, James. (2009). "Contemporary, Moral problems War, Terrorism and Torture" Belmont: Wards worth Cengage Learning.

Wisnewski, J. Jermy. (2010). "Understanding Torture" Edinburgh universities press. 